\title{
Towards at least one more Canadian consensus
}

\author{
ABR THOMSON, MD, FRCPC, FACC
}

A CHIEVING A CANADIAN CONSENSUS REPRESENTS A challenge of the minds, fruit for the lion-hearted, not for the frivolous or the faint. The future rests on a 55/45 verdict. What a remarkable accomplishment that a $40 / 0$ accord could be accomplished on a practical approach to the management of patients with gastroesophageal reflux disease (GERD - page 277). From the discussion, the debate, came social pressures, unchallenged principles, decision points of opinion not substantiated by data but rather by belief. And yet, in any process for change whether it be for a better tomorrow or a just society, we need a beginning from which we may develop a model for examination and review. This was what was accomplished, a sensible beginning for practice, safe, reasonable practice guidelines for all practitioners. Not self-serving either, for the very endoscopists whose livelihood might be affected by a proposal to reduce the indications for a favourite procedure, recognized the need for constraint, a focusing of resources in the hope that these very resources would still be there when clearly and urgently indicated.

Remarkable that the Europeans also have a similar pragmatic approach to Managing Life with Acid Reflux Disease (First United European Gastroenterology Week, Athens, Greece, September 28, 1992). The prevalence of reflux symptoms among the adult population ranges from $26 \%$ for a six-month prevalence of heartburn and regurgitation (1), to 37 to $40 \%$ for a 12 -month period $(2,3)$. If we are to base a diagnosis of GERD on symptoms, and compare this with a 'gold' or at least 'silver standard' of $24 \mathrm{~h} \mathrm{pH}$ monitoring, we need to know sensitivity, specificity and positive predictive

Correspondence: Dr ABR Thomson, University of Alberta, 519 Robert Newton Research Building, Edmonton. Alherta T6G 2C2 value of heartburn and regurgitation: 24 to $38 \%, 63$ to $89 \%$ and 66 to $81 \%$, respectively $(4,5)$. The assumption of the Canadian Consensus decision tree (Figure 1) is based on these figures, allowing the comfort of using empirical treatment without initially subjecting all persons to costly, and apparently often unnecessary, investigations.

"But", you may say, "my office is booked full with patients with the irritable bowel syndrome, not with GERD. If the prevalence data is correct, something doesn't fit." To make a good fit, we need to recognize a further important factor not acid, pepsin or sphincter pressures - but rather the determinants of health-seeking behaviour. Those persons with GERD symptoms who consult a physician are more likely than nonconsulters to be worried that they have cancer, heart disease or some other possibly serious or fatal condition (6). So, part of our management of persons/patients with GERD must be to address quality of life issues, to ascertain what is the source of the anxiety.

The correlation between symptoms and 'pH-metry' is reasonable (7), but not so for endoscopy $(8,9)$. So why are we so often gazing at a video screen to grade the severity of esophagitis? Where is the evidence for endoscopic healing being associated with fewer recurrences or fewer complications? Certainly, recurrence rates for symptoms and for esophagitis are high so there may well be a good reason to identify the presence of esophagitis. Further investigation is appropriate for those persons with (a) alarm symptoms (dysphagia, weight loss, anemia, bleeding - worry: cancer or stricture); (b) persisting symptoms after eight to 14 weeks of treatment; or (c) recurring symptoms after recently successful therapy (worry: erosive esophagitis requiring more potent acid inhibition and/or maintenance therapy). Dr John R Bennett has provided a flow chart for empirical symptomatic 


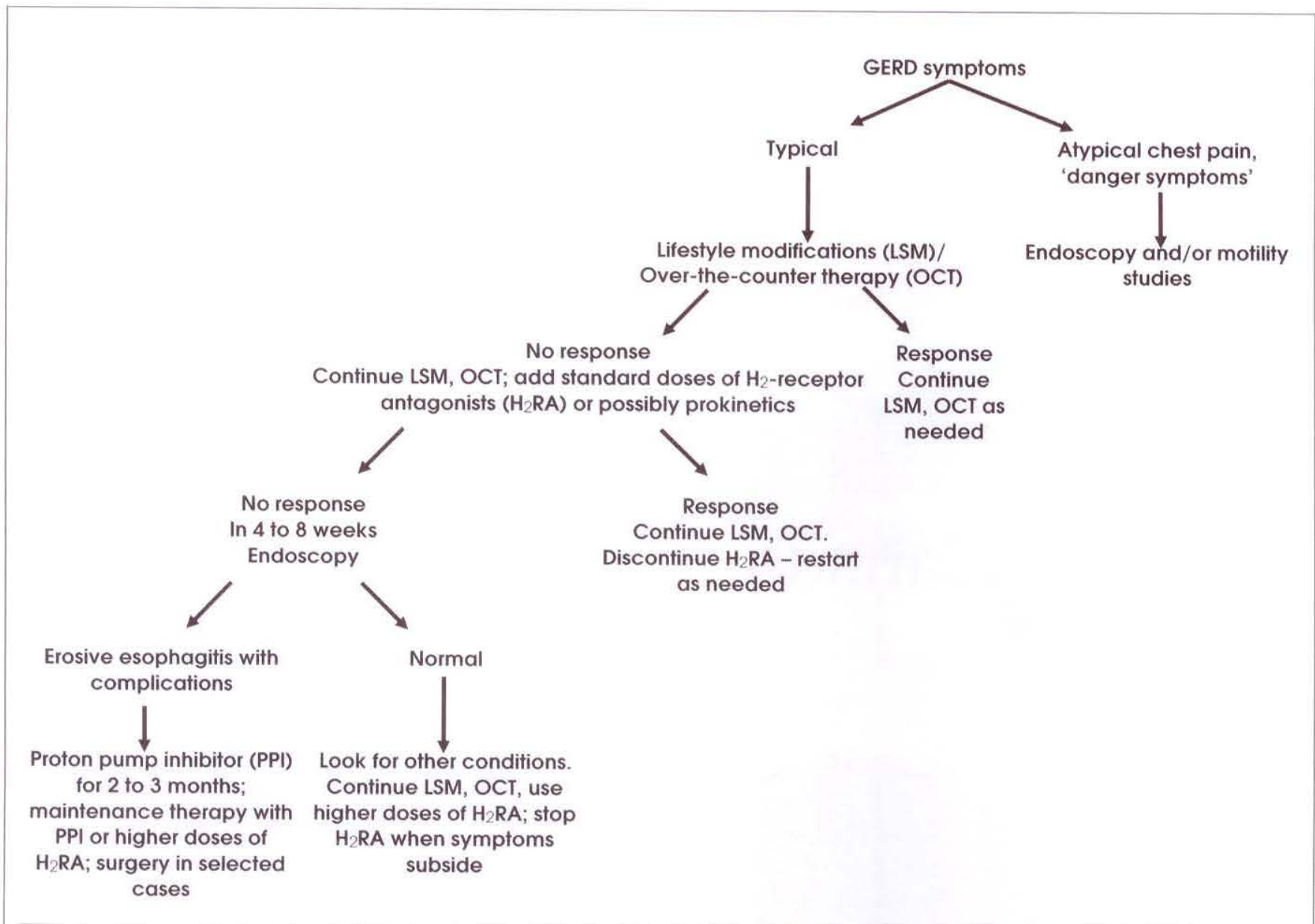

Figure 1) Canadian GERD Consensus decision tree

treatment of GERD (Figure 2) which is remarkably similar to that obtained through our own independent Canadian consensus (10). Hz-receptor antagonists "provide similar effective symptom relief when given in equivalent dosage regimens". While superior symptom improvement can be achieved with a proton pump inhibitor rather than an $\mathrm{H}_{2}$ receptor antagonist (11), this study was not designed to control vigorously for the assessment of follow-up endoscopies, nor is it generally accepted that more potent acid suppression be undertaken initially in all persons. Why not? Because. Because, why? Well, you decide - the adverse effect profile for short term use of proton pump inhibitors and $\mathrm{H}_{2}$-receptor antagonists is equally impressive. One could argue that an agent of superior efficacy and equivalent cost and safety profile be used for an endoscopy, but that was not the consensus. Perhaps to identify better those persons requiring an endoscopy to identify erosive disease, which is often associated with recurrences and may require appropriate discussion of the use of maintenance therapy. But patients with erosive esophagitis treated with either an $\mathrm{H}_{2}$ receptor antagonist or a proton pump inhibitor for eight to 12 weeks and who then come off therapy will quickly recur - some even suggest that those coming off acute treatment with a proton pump inhibitor might recur more quickly, so that an endoscopic study would be done at that point anyway. Some further reflection is needed on this contentious point. And for the patient who has a rapid return of frequent symptoms after coming off acute therapy (again with no alarm symptoms), what do we do if endoscopy is normal? Probably more of the same, another course of an $\mathrm{H}_{2}$-receptor antagonist (or a proton pump inhibitor) for eight to 12 weeks. And then? Off treatment again. What if the symptoms recur yet again? Some suggest that it is unnecessary to perform a second procedure. Yet do we know that the underlying assumption is correct, that once a normal endoscopy for GERD, always a normal endoscopy? A Wayne's World 'NOT'! So why not simply use intermittent therapy, cycles of $\mathrm{H}_{2}$-receptor antagonists or proton pump inhibitors for cycles of recurrent heartburn. Then, if symptoms frequently recur, consider maintenance therapy with a proton pump inhibitor or an $\mathrm{H}_{2}$-receptor antagonist or a prokinetic such as cisapride $(12,13)$. The dose of acid-inhibitory therapy may need to be adjusted to normalize the percentage of time the esophageal $\mathrm{pH}$ is greater than 4 (14), but where is the evidence that this stepwise increase in dose of $\mathrm{H}_{2}$ receptor antagonist or proton pump inhibitor cannot be done based just on patient response, without further endoscopies? 


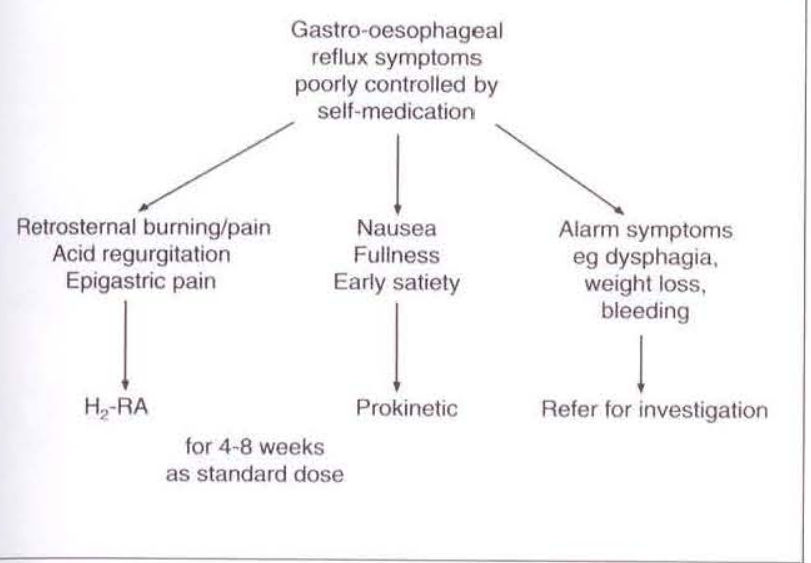

Figure 2) Empirical symptomatic treatment of GERD (reprinted with permission from reference 10 )

Are there lessons from the management of patients with duodenal or gastric ulcer disease which can be applied to patients with GERD? Like GERD, peptic ulcer disease is prone to a long duration of symptoms, remaining active for 25 years or more in about $25 \%$ of individuals (15), with the everpresent risk of hemorrhage or perforation. Many different factors predispose to recurrence (Table 1), and the likelihood of duodenal ulcer disease recurrence depends on the number of risk factors. We do not yet know if the same factors, or principles, present in GERD, but this is certainly a reasonable working hypothesis, subject to future testing - even the possibility that Helicobacter pylori infection may be more common in persons with GERD. Of course, in GERD (let alone duodenal ulcer disease) the time has not yet come for indiscriminate attempts to stamp out $H$ pylori (16). While symptomatic recurrences of GERD and duodenal ulcer disease can both be prevented with continuous therapy, it is only in the latter that factors have been identified which have an adverse influence on recurrence rates during continuous $\mathrm{H}_{2}$ receptor antagonist treatment: these include smoking, stress, previous history of frequent ulcer relapses, and duration of disease for more than 10 years (17). While there is clear evidence for all the $\mathrm{H}_{2}$-receptor antagonists being superior toplacebo for maintenance therapy in duodenal ulcer disease (18), and evidence for lower duodenal ulcer recurrence rates with ranitidine than with cimetidine $(19,20)$, we do not yet have comparative data for different $\mathrm{H}_{2}$-receptor antagonists in GERD. We know that the risk of duodenal ulcer disease recurrence is kept low for as long as nine years with ranitidine maintenance therapy (21). We do not yet know how long to continue maintenance therapy in GERD; certainly good oneyear remission rates may be achieved using 150 or $300 \mathrm{mg}$ ranitidine bid. One advantage of using ranitidine $300 \mathrm{mg}$ versus $150 \mathrm{mg}$ for maintenance therapy in duodenal ulcer disease is the lowering of recurrence rates in smokers to the level seen in nonsmokers. There is the preliminary suggestion that prolonged treatment with $\mathrm{H}_{2}$-receptor antagonists reduces the risk for ulcer recurrence once therapy has been

\section{TABLE 1}

Factors associated with high duodenal ulcer recurrence rates

\begin{tabular}{ll}
\hline Clinical & - younger patients, male sex \\
& - family history \\
Anatomical & - refractoriness \\
& - partial healing on enteral long term \\
& - management \\
Functional & - high BAO, MAO, PAO \\
& - high nocturnal acid secretion \\
& - increased peptic activity \\
Exogenous & cigarette smoking \\
& - NSAID intake \\
&
\end{tabular}

discontinued $(22,23)$. However, others argue that maintenance therapy must be continued for many years, perhaps at least 15 years, when the natural history of the disease has allowed it to become 'burned out' $(15,24)$.

The maintenance dose for duodenal ulcer disease is onehalf the standard ulcer-healing dose, but patients with GERD may need to be maintained on full doses of $\mathrm{H}_{2}$-receptor antagonists. Does this have adverse effects? Clinically important hypergastrinemia has not been described in patients with duodenal ulcer disease after five years of treatment with ranitidine (25), and we await with great interest the outcome of a major duodenal ulcer disease maintenance study using omeprazole.

A new field is under cultivation - pharmacoeconomic considerations. There are important direct as well as indirect costs, and it is inefficient to consider just the cost of medication without also establishing the cost of investigations, institutional care and lost productivity, let alone the value of a person remaining pain-free. About one-third of direct costs relates to drugs (26), and direct costs may be less than half of the total cost (27). In a French multicentre study, maintenance therapy for duodenal ulcer disease with ranitidine $150 \mathrm{mg} /$ day for 12 months resulted in a $29 \%$ decreased total cost of duodenal ulcer disease compared with no maintenance therapy (28). Continuous treatment with ranitidine was twice as cost-effective as intermittent treatment. In the United States, continuous versus intermittent therapy with ranitidine reduces the cost of one successfully treated patient by $12 \%$, or about $\$ 100$ (Canadian) per year (29). Another American study has shown that for at least 15 years continuous and intermittent treatment are of similar cost, and cheaper than surgery (30).

Many unknowns, but we have begun to sketch out the map for the future, to frame the problem in a context which may be tested, and improved upon. Please read the Consensus Document in this issue (page 277) with interest, and send us your comments. 


\section{REFERENCES}

1. Ruth M, Mansson I, Sandberg N. The prevalence of symptoms suggestive of oesophageal disorders. Scand J Gastroenterol 1991;26:73-81.

2. Nebel OT, Fornes MF, Castell DO. Symptomatic gastro-oesophageal reflux: Incidence and precipitating factors. Dig Dis 1976;21:953-6.

3. Jones RH, Lydeard SE, Hobbs FDR, et al. Dyspepsia in England and Scotland. Gut 1990;31:401-5.

4. Johnsson F, Joelsson B, Gudmundsson K, Greiff L. Symptoms and endoscopic findings in the diagnosis of gastro-oesophageal reflux disease. Scand ] Gastroenterol 1987;2:714-8.

5. Klauser AG, Schindlbeck NE, Muller-Lisaner SA. Symptoms in gastro-oesophageal reflux disease. Lancet 1990;335:205-8.

6. Lydeard S, Jones R. Factors affecting the decision to consult with dyspepsia: Comparison of consulters and non-consulters. J R Coll Gen Pract 1989;39:495-8.

7. Mattioli S, Pilotti V, Spangaro M, et al. Reliability of 24 hour home esophageal $\mathrm{pH}$ monitoring in diagnosis of gastroesophageal reflux. Dig Dis Sci 1989;34:71-8.

8. Johansson K-E, Ask P, Boeryd B, Fransson S-G, Tibbling L. Oesophagitis, signs of reflux, and gastric acid secretion in patients with symptoms of gastro-oesophageal reflux disease. Scand J Gastroenterol 1986;21;837-47.

9. Winters C, Spurling T], Chobanian S], et al. Barrett's esophagus. A prevalent occult complication of gastroesophayeal reflux disease. Gastroenterology 1987;92:118-24

10. Bennett JR. A practical approach to patient management. First United European Gastroenterology Week, Athens, Greece, 1992. (Abst)

11. Cleator IGM, Williams CN, Archambault AP, Taylor DW, Thomson ABR, Hunt RH, Sutherland LR, with the Canadian Collaborative Study Group. A comparison of the clinical efficacy and safety of Losec (B) (omeprazole) and Zantac $(B)$ (ranitidine) in the clinical management of uncomplicated duodenal ulcer and gastroesophageal reflux disease. (In press)

12. Halvorsen L, Hazenberg BP, Hegarty T, Nowak A, Smith C, Thomson ABR, Van Trappen G. Effect of two ranitidine dosage regimens on prevention of relapse in patients with reflux oesophagitis. Hellenic J Gastroenterol 1992;5(Suppl):438. (Abst)

13. Tytgat GNJ, Anker Hansen OJ, Carling L, et al. Effect of cisapride on relapse of reflux oesophagitis, healed with antisecretory drug. Scand J Gastroenterol 1992;27:175-83.

14. Robertson DAF, Aldersley MA, Shepherd H, Lloyd RS, Smith CL. $\mathrm{H}_{2}$-antagonists in the treatment of reflux oesophagitis: Can physiological studies predict the response? Gut 1987;28:946-9.
15. Fry J. Peptic ulcer: A profile. Br Med J 1964:2:809-12.

16. Walsh JH. Helicobacter pylori: Selection of patients for treatment. Ann Intern Med 1992;116:770-1.

17. Armstrong D, Blum AL, Arnold R, Classen M, Goebell H, Fischer M, and the RUDER Study Group. A 2-year prospective study of risk factors for recurrent duodenal ulceration in 1899 patients. Gastroenterology 1991;100(5, part 2):A27.

18. Palmer RH, Frank WO, Karlstadt R. Maintenance therapy of duodenal ulcer with $\mathrm{H}_{2}$-receptor antagonists - a metaanalysis. Aliment Pharmacol Therap 1980;4:283-94.

19. Kurata JH, Koch GG, Nogawa AN. Comparison of ranitidine and cimetidine ulcer maintenance therapy. J Clin Gastroenterol 1987;9:644-50.

20. Gough KR, Bardhan KD, Crowe JP, et al. Ranitidine and cimetidine in prevention of duodenal ulcer relapse. Lancet 1984;ii:659-62.

21. Penston JG, Wormsley KG. Nine years maintenance treatment with ranitidine for patients with duodenal ulcer. Aliment Pharmacol Therap 1992;6:629-46.

22. Susi D, Neri M. The natural history of duodenal ulcer disease is modified after discontinuing a five years maintenance therapy with ranitidine. Gastroenterology 1991;100:A170.

23. Holtmann G, Armstrong D, Blum AL, et al. Effects of 2-year maintenance therapy with ranitidine on the natural course of duodenal ulcer disease. Gastroenterology 1992;102 (4, part 2):A84.

24. Krause U. Long-term results of medical and surgical treatment of peptic ulcer. Acta Chir Scand 1963;125(Suppl 310):5-11.

25. Penston JG, Wormsley KG. Long term maintenance treatment of gastric ulcers writh ranitidine. Aliment Pharmacol Therap 1990;4:339-55.

26. Ruszniwski P. The cost of duodenal ulcer disease in France: $A$ macroeconomic inquiry. In: Mignon M, Gaomiche JP, eds. Safe and Effective Control of Acid Secretion. London, Paris: John Libbey Eurotext 1988;275-83.

27. Levy E. Economic evaluation in health: The case of duodenal ulcer. In: Mignon M, Galmiche JP, eds. Safe and Effective Control of Acid Secretion. London, Paris: John Libbey Eurotext 1988;249-61

28. Ruszniwski P, Levy E, Mignon PM, et Groupe d'Etude de la Maladie Ulcereuse Duodenale (GEMUD). Analyse economique du traitement d'entretien de la maladie ulcereuse duodenale par la ranitidine $150 \mathrm{mg}$. Gastroenterol Clin Biol. (In press)

29. Van Deventer GM, Osterhaus JT. Pharmacoeconomic benefits of ranitidine maintenance therapy. A retrospective analysis of a clinical trial. J Clin Res Pharmacoepidemiol 1992;6:29-37.

30. Sonnenberg A. Costs of medical and surgical treatment of duodenal ulcer. Gastroenterology 1989;96:1445-52. 


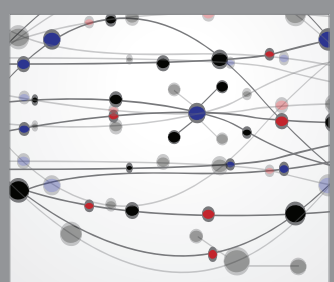

The Scientific World Journal
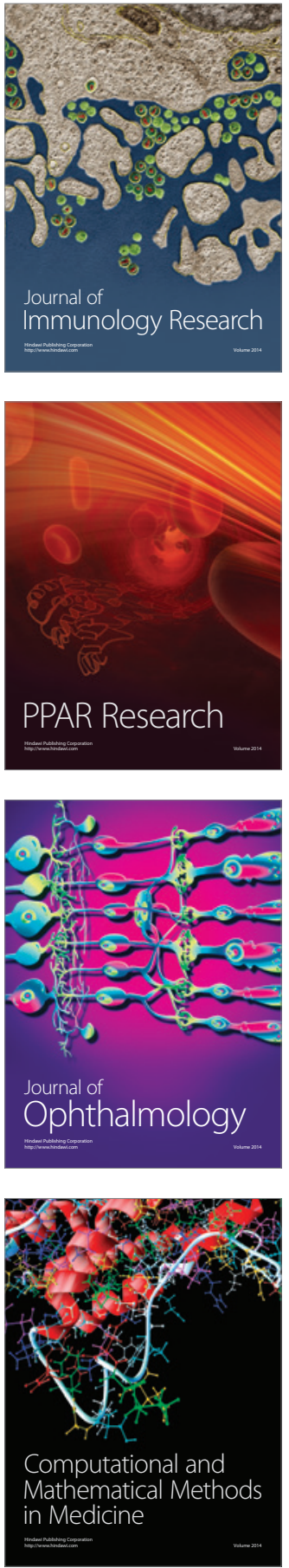

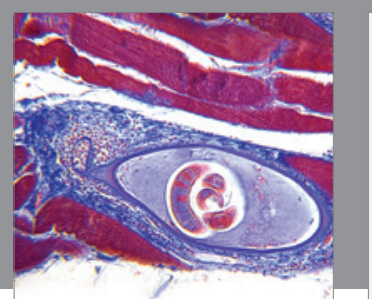

Gastroenterology Research and Practice

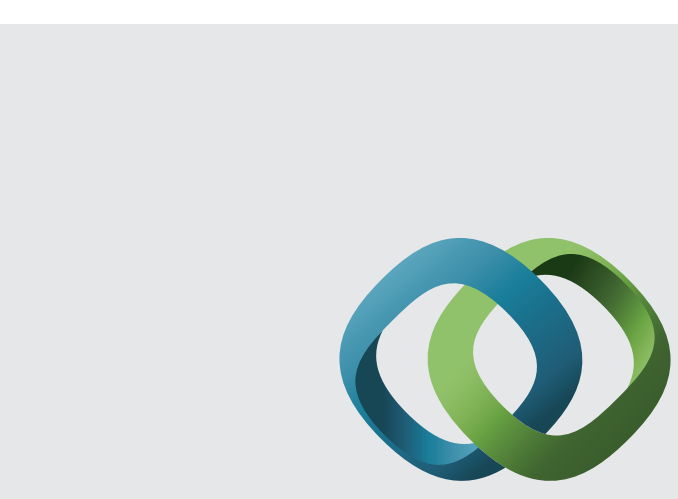

\section{Hindawi}

Submit your manuscripts at

http://www.hindawi.com
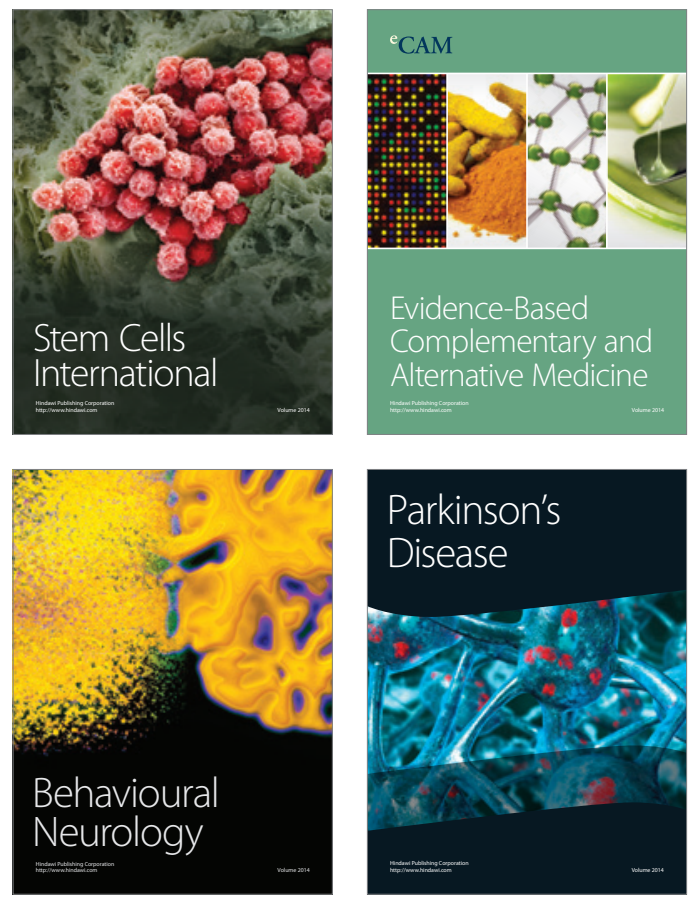
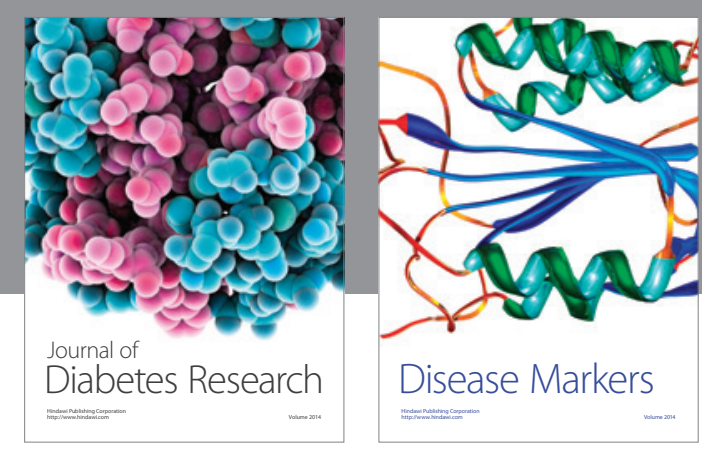

Disease Markers
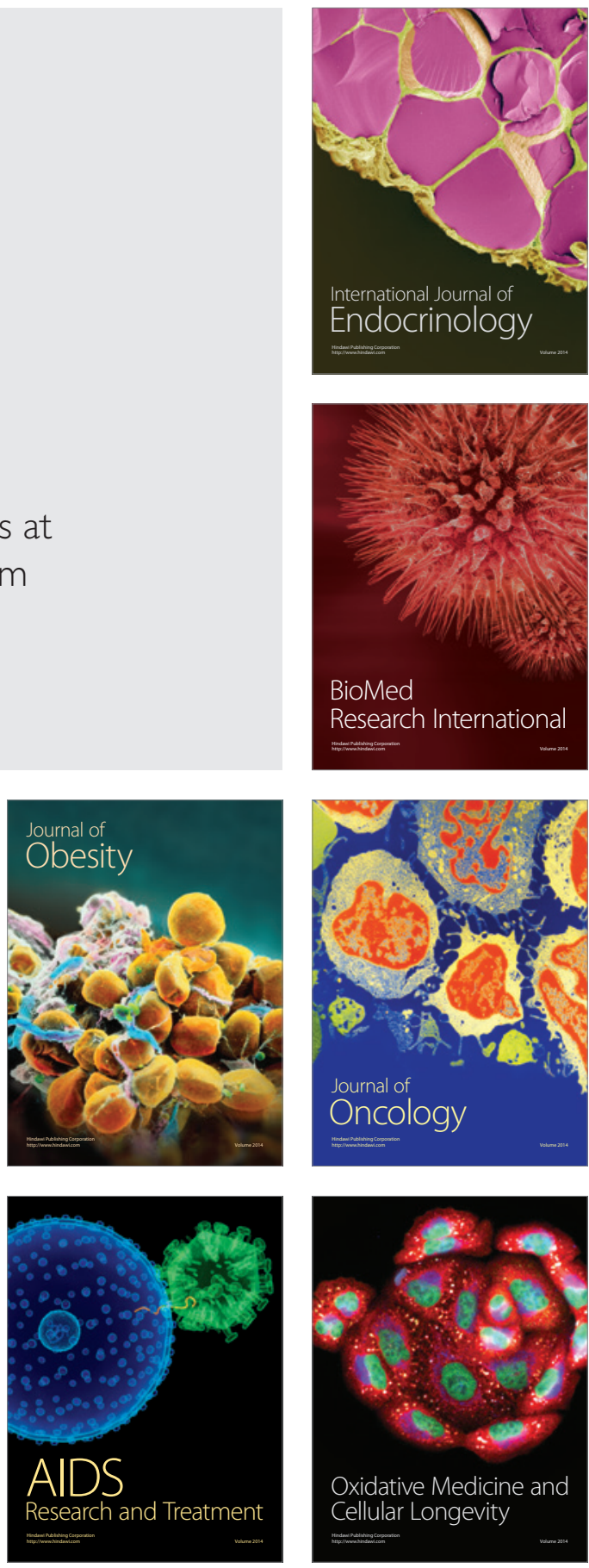